DOI 10.32726/2411-3417-2019-4-82-91

УДК $327 ; 329$

\title{
АлександР Полунов
}

\section{Общественные организации Крыма в 2005-2010 гг.: борьба за национально-культурную идентичность русского населения}

\begin{abstract}
Аннотация. В статье анализируются общественно-политические и идейные предпосылки прочессов, которые развернулись на Крымском полуострове весной 2014 2. и завершились его возвращением в состав России. В чентре внимания автора - период 2005-2010 г2., когда в Киеве утвердилась «оранжевая власть» во главе с президентом В.Ф. Ющенко. Рассматривается деятельность общественных организаций и политических партий Крыма, выражавших интересы русского населения, их позиции по ключевым внутри- и внешнеполитическим вопросам. Показано, что в ходе деятельности организаций русского населения между ними возникли серьезные разногласия, которые в конечном счете удалось преодолеть.
\end{abstract}

Ключевые слова: Крым, автономия, независимость, русское население, общественные организачии, политические партии, «оранжевая революция», идеология, культура.

$\prod$ ри обращении к новейшей истории Крыма представляется важным выявить предпосылки тех событий и процессов, которые развернулись на полуострове весной 2014 г. и завершились его возвращением в состав России. Особое значение имеет период 2005-2010 гг., характеризовавшийся утверждением в Киеве после «первого майдана» «оранжевой власти» во главе с президентом В.Ф. Ющенко. Именно в эти годы окончательно сложилась позиция политически активного русского населения Крыма в отношении киевской власти.

Для Крыма, как и для многих регионов бывшего СССР, рубеж 1980-х - 1990-х годов стал временем возникновения независимых общественных организаций и складывавшихся на их базе идейных течений. Задачей общественных организаций Крыма с самого начала являлась защита национально-культурной, исторической и языковой идентичности русского населения полуострова.

В условиях общественно-политической турбулентности, порожденной «перестройкой», нарастания процессов дезинтеграции союзного государства на полуострове громко звучали лозунги создания Крымской республики в составе СССР и закрепления

Сведения об авторе: ПОЛУНОВ Александр Юрьевич - заведующий кафедрой управления в сфере межэтнических и межконфессиональных отношений факультета государственного управления МГУ имени М. В. Ломоносова, заместитель декана по научной работе, доктор исторических наук, профессор, polunov@spa.msu.ru. 
на ее территории статуса русского языка в качестве государственного'. После распада Советского Союза представители политически активного русского населения широко использовали для продвижения своих требований институты электоральной демократии. Президентом Крыма в 1994 г. был избран Ю.А. Мешков - известный деятель пророссийской направленности. В Верховном Совете автономии его поддерживал блок «Россия», завоевавший большинство депутатских мест. Как утверждал впоследствии первый секретарь Крымского республиканского комитета Коммунистической партии Украины (КПУ) Л.И. Грач, «посредством выборов в начале 1990-х... был реализован лозунг о возврате Крыма в Россию» [Грач].

Но вскоре у пророссийского движения начались проблемы. Несмотря на триумфальную победу на выборах, руководство Крыма не смогло обеспечить полуострову реальную автономию - для этого не было сколько-нибудь значительной финансовоэкономической базы. Сказывались и недостаток управленческого опыта у лидеров, и преобладание в их окружении политиков «митингового» типа, что было вообще характерно для начала 1990-х годов. Наконец, пророссийское движение ориентировалось на Россию, а поддержки с ее стороны не дождалось. Руководство Российской Федерации в те годы рассматривало выступления пророссийских деятелей за рубежом как досадную помеху на пути сближения с Западом и скорейшей интеграции в евроатлантические структуры. Были опасения, что это может возродить на Западе подозрения относительно «неизжитых имперских амбиций» России.

В этих условиях руководство Украины, умело манипулируя крымскими политиками, добилось в 1995 г. изменения конституции и ликвидации поста президента автономии, что стало тяжелым ударом для организаций русского населения Крыма.

Возрождение политической активности пророссийских сил полуострова началось в 2002 г. В Верховный Совет Крыма прошли депутаты от новых общественно-политических структур - организации «Русская община Крыма» и партии «Русский блок». На очередных выборах спустя четыре года они расширили свое представительство.

Лозунги «оранжевой революции» 2004 г. были восприняты значительной частью населения полуострова враждебно.

В 2008 г., в связи с провозглашением независимости края Косово, конфликтом в Закавказье и признанием независимости Южной Осетии и Абхазии со стороны России, обстановка еще более осложнилась.

По словам газеты «Первая Крымская», «события в сербском крае всколыхнули на Украине и в Крыму новую волну заявлений о сепаратизме, патриотизме, национализме

1 По результатам референдума, состоявшегося в январе 1991 г., Крыму был присвоен статус автономной республики, но в составе не СССР, а Украины. Одновременно с конца 1980-х годов началось возвращение на полуостров депортированного в 1944 г. крымско-татарского населения, значительно обострившее социальные и этнические противоречия в Крыму. 
и праве на самоопределение». Л.И. Грач предположил, что признание Западом независимости Косова дает повод пророссийским силам на полуострове вновь поставить вопрос о правомерности «дарения» Крыма Украине в 1954 г. Лидеры крымских татар заявили, что автономию необходимо преобразовать из территориальной в национальную (татарскую). В то же время организации украинских националистов потребовали лишить Крым автономных прав [На Украине есть...].

Болезненное протекание начавшегося в 2008 г. мирового финансово-экономического кризиса дало повод представителям русских организаций говорить о неспособности украинского государства обеспечить стабильное развитие экономики и защитить социальные права своих граждан.

Но сильнее всего сказались на настроениях русского населения события в Южной Осетии и последовавшее за ними провозглашение независимости Южной Осетии и Абхазии. Верховный Совет Автономной Республики Крым принял обращение к Верховной Раде Украины, выразив «поддержку народам Абхазии и Южной Осетии в их праве на самоопределение» и одобрив «действия Российской Федерации по обеспечению их безопасности». Русскую общину Крыма, инициировавшую это обращение, поддержали представители крымских республиканских отделений Партии регионов, партии «Русский блок», Коммунистической партии Украины, Прогрессивной социалистической партии Украины, ряд городских советов, республиканские национально-культурные общества.

В июне 2009 г. Русская община Крыма направила участникам VII Всемирного съезда осетинского народа приветственное послание, в котором говорилось: «Мы, крымчане, солидарны с братским осетинским народом и желаем ему единения, свободы, успехов в восстановлении разрушенного хозяйства».

Активизация политики официального Киева в этот период вызывала у организаций русского населения резко отрицательную реакцию. Именно так была воспринята, например, подписанная в декабре 2008 г. руководителями внешнеполитических ведомств Украины и США Хартия стратегического партнерства, предполагавшая, в частности, открытие в Симферополе дипломатического представительства США с неясными статусом и функциями. Лидер Русской общины Крыма Сергей Цеков во время встречи с американским послом на Украине У. Тэйлором в январе 2009 г. заявил, что открытие «поста присутствия» США в Крыму послужит поводом к постоянным конфликтам и напряженности. Он подчеркнул, что значительная часть населения Крыма не доверяет США из-за их политики по отношению к России и курса на безусловную поддержку киевского правительства: «В Крыму проживает 60 процентов русских по национальности, 80 процентов по языку - вы обязаны эти реалии учитывать! Россия для нас Родина, и мы не предадим ее, и вы это должны знать. Это реальность, с которой нужно считаться» [Скольких крымчан...].

Еще в январе 2008 г. Севастопольский городской совет единогласно провозгласил город «территорией без НАТО». Депутаты заявляли, что «оставляют за собой право 
в случае продолжения курса на вступление Украины в НАТО призвать жителей Севастополя к массовым акциям протеста». Это, в свою очередь, подталкивало официальный Киев к сближению с блоком НАТО. Можно упомянуть обращение президента Ющенко к руководству блока с просьбой о включении Украины в План действий по членству в НАТО, план проведения на территории полуострова совместно с войсками блока учений «Си Бриз» и др. Ряд украинских политиков и общественных организаций (прежде всего из западных регионов страны) поставили вопрос о лишении Севастополя особого статуса, об ограничении и даже ликвидации крымской автономии.

Все это не могло не способствовать дальнейшему сплочению политически активного русского населения полуострова. Вместе с тем на пути такого сплочения оказалось немало серьезных препятствий.

Главное из них - разногласия в среде крымских пророссийских организаций, вызванные в том числе и тем, что их представители не могли быть уверены (даже после 2000 г.) в твердой поддержке своих действий со стороны России. Поэтому делались попытки найти для Крыма приемлемое место в политической системе украинского государства.

Подобное место, по словам лидера Русской общины Сергея Цекова, могло быть обеспечено посредством федерализации государства и провозглашения русского языка вторым государственным. «Это - два основных момента, которые, если они будут

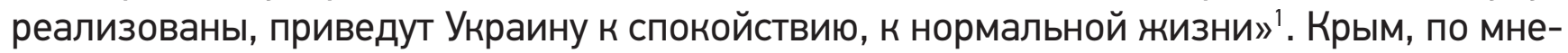
нию сторонников подобной точки зрения, должен был строить отношения с официальным Киевом на договорных основах, что явилось бы единственной прочной гарантией автономии республики [Крымчане отпраздновали...].

Сторонники более радикального подхода решительно выступали против пребывания полуострова в составе Украины. С их точки зрения, осуществленная Н.С. Хрущевым в 1954 г. без учета мнения крымчан передача полуострова Украине явилась для русского населения Крыма «депортацией», а проводившаяся официальным Киевом политика украинизации представляла собой «этноцид». Как считали руководители Народного фронта «Севастополь-Крым-Россия», жители Крыма и Севастополя «оказались вне Родины... по воле безумцев, предателей и явных врагов», а Украина после развала СССР осуществила «аннексию» Крыма, т.е. неправовую акцию. В документах Народного фронта подчеркивается, что Украина, «как и все государства, имеет право на суверенитет, независимость, но без уворованных у России земель и компактно проживающих на них миллионов русских» [Декларация...].

«Сегодняшний Крым - это мятежная территория, над которой Украина потеряла контроль», - констатировал в июле 2008 г. независимый информационный ресурс «Непокоренный Крым». В том же году сайт извещал читателей, что «украинский проект в Крыму уже давно провалился», «независимость будет провозглашена в односторон-

1 С. Цеков: «Все это мы уже слышали от товарища Сталина» [Цит. по: Цеков]. 
нем порядке, когда начнется развал Украины». По мнению авторов сайта, движение за автономию и даже независимость охватит не только Крым, но и Донбасс, Подкарпатскую Русь, Буковину. «Обанкротившейся Украине придется скоро расстаться со всеми этими территориями и влачить свое жалкое существование уже в усеченном виде»'.

Однако столь непримиримо по отношению к украинскому государству были настроены не все из представителей политически активной части русского населения. «Мы не против Украины, но мы против той политики, которую последние 17 лет проводит независимая Украина», - заявил председатель исполкома Русской общины Крыма О.А. Слюсаренко 19 февраля 2009 г., в день симферопольского шествия, посвященного 55-й годовщине передачи Крыма в состав Украинской ССР.

Депутат Верховной Рады Леонид Грач вместе с представителями Русской общины Крыма и партии «Русский блок», сотрудничавшими с Партией регионов, стремились найти компромисс с официальным Киевом. Они работали над формулировками, способными устроить различные общественные силы. «Мы - интеграционисты, — заявил заместитель председателя «Русской общины Крыма» Олег Радивилов в интервью информационному агентству «Росбалт» в июне 2009 г. - Воссоединение с Россией процесс исторический. Мы, русские Крыма, хотели бы сделать это законным путем, в рамках парламентской деятельности... Если Крым хочет быть субъектом Союзного договора, это не значит, что он хочет выйти из состава Украины. Он просто может быть субъектом Таможенного союза или какого-либо другого объединения. Львову и Закарпатью будем объяснять, что ничего плохого для них интеграция с Россией не несет»[Радивилов].

По мнению руководителей Русской общины Крыма, организации русского населения были призваны «усилить восточный геополитический вектор в развитии современной Украины», «развернуть украинский государственный корабль... в сторону восстановления союзнополитических отношений Украины с Россией». О.А. Слюсаренко считал важным, чтобы «в обозримом будущем... Украину в мире и на переговорах с Россией» не представляли политики, «далекие от интересов России и Славяно-Русского мира в целом»². Политики «умеренного» крыла отмечали, что сохранение Крыма в составе Украины будет побуждать ее идти на сближение с Россией. Лидер крымских коммунистов Л.И. Грач подчеркивал, что полуострову «уготована сложнейшая миссия - миссия якоря, удерживающего Украину у берегов России» [Грач]. Подобные рассуждения вызывали недовольство радикально настроенных организаций.

1 Интересно в этой связи заметить, что еще в 2006 г. руководство Народного фронта направляло Юрию Мешкову приглашение вернуться в Крым в качестве легитимного президента автономии. «Никто из крымчан-патриотов не считает его недействительным президентом, - утверждал координатор Народного фронта С. Компаниец. - Как раньше французы считали де Голля, так и мы Мешкова считаем президентом в изгнании. И он имеет полное моральное и юридическое право возглавить сейчас патриотические силы Крыма» [Компаниец].

2 См. информационную справку о «Русской общине Крыма» на веб-сайте этой организации: ruscrimea.ru/?id=rok/spravka 
Разногласия были вызваны не только различными подходами к судьбе полуострова, но и программными установками тех или иных сил. Так, Леонид Грач характеризовал Партию регионов как «бюрократическую, либерально-буржуазную партию крупного олигархического капитала», которая подвергается манипулированию со стороны США. В свою очередь, в выступлениях представителей Народного фронта «Севастополь-Крым-Россия» сам Грач представал как «жесткий украинский государственник», да еще и приверженец идеологии марксизма-ленинизма. Деятели Народного фронта призывали Грача «расстаться с обанкротившейся коммунистической идеологией и начать деятельность на благо полуострова».

Что касается «умеренного» крыла Русской общины Крыма, они в целом положительно оценивали деятельность Партии регионов, полагая, что она играет конструктивную роль в рамках сложившегося на Украине политического баланса. «Это очень хорошо, - заявлял Цеков в интервью информационному агентству «Новый регион» 22 января 2009 г., - когда одна политическая сила (в данном случае Партия регионов) действует осмотрительно и осторожно, а другая, то есть Русская община Крыма и Русский блок, настроены более радикально. В итоге нам удается принимать взвешенные решения, которые однозначно полезны для Крыма и крымчан».

А вот руководство Народного фронта, как и Леонида Грача, не устраивала недостаточно последовательная, на их взгляд, политика Партии регионов по отношению к НАТО и защите русского языка. «Партия регионов в лице Януковича отказалась от своих главных предвыборных обещаний, - заявил координатор Народного фронта Валерий Подъячий корреспонденту ИA REGNUM. - Это неудивительно, потому что уже давно просматривалось стремление верхушки регионалов выгодно продать своих избирателей в обмен на портфели» [Виктор Янукович...].

В этих условиях стали неизбежными разобщенность действий организаций русского населения и, как следствие, недостаточная эффективность их начинаний. «В Крыму нас (представителей русского населения - А.П.) 80 процентов, но говорить, что мы действуем очень эффективно, к сожалению, не приходится», - был вынужден признать Сергей Цеков в интервью агентству «Новый регион». Еще категоричнее высказывались политики, занимавшие более радикальные позиции. «Пророссийские политические силы Крыма разрозненны и, по сути, стали на путь финансового крохоборства. Они противодействуют друг другу и, таким образом, льют воду на мельницу антикрымских сил», - заявил Леонид Грач в интервью ИA REGNUM. Разногласия внутри пророссийского движения Крыма отразились в конфликтах, разделявших представителей Русской общины Крыма и КПУ в Верховном Совете Крыма, в отходе отдельных должностных лиц от пророссийских лозунгов, с которыми они шли на выборы. Серьезным фактором, отрицательно влиявшим на деятельность организаций русского населения, оставалось отсутствие внятной политики и поддержки со стороны России.

Следует подчеркнуть, что курс на единство с исторической родиной, сохранение исторической памяти, чувства принадлежности к общей культуре занимал важнейшее место в деятельности крымского пророссийского движения. Организациями русской 
общины в течение всего рассматриваемого периода регулярно проводились мероприятия, связанные с памятью о важнейших вехах российской истории. Во время их проведения особо подчеркивалась необходимость единства с исторической родиной. Так, во время демонстраций в Симферополе 1 и 9 мая 2009 г. участники несли российские флаги, портреты Д.А. Медведева и В.В. Путина, скандировали лозунги «Слава великой России!», «Слава русскому народу-победителю!». К числу мероприятий, направленных на сохранение исторической памяти, относились празднования годовщины присоединения Крыма к Российской империи и дня рождения Екатерины II, возведение памятных знаков в честь пребывания в Крыму представителей династии Романовых. Вместе с тем конкретные аспекты поведения России на международной арене в целом и ее политики по отношению к Крыму вызывали у представителей русских организаций весьма противоречивые оценки.

При отсутствии четко выраженной поддержки со стороны России значительная часть политически активного русского населения предпочитала придерживаться легальных методов деятельности, действовать в правовом поле Украины. Недовольство пребыванием в составе украинского государства, распространенное среди русского населения Крыма, объяснялось в данном контексте политикой официального Киева, нарушением неотьемлемых прав человека на территории Крыма. Широкое распространение среди деятелей русских организаций получила правозащитная аргументация, стремление привлечь внимание мирового сообщества к своим проблемам. Так, в сентябре 2008 г. Леонид Грач, возглавлявший Общественный совет по защите конституционных полномочий Автономной Республики Крым, направил обращение «О грубом нарушении правящим режимом Украины основных конституционных полномочий Автономной Республики Крым» в адрес ООН, Совета Европы, ОБСЕ, правительств России, США и других государств. К числу нарушений, перечисленных в обращении, относились: ограничение сферы применения русского языка, проведение на территории полуострова учений НАТО, нарушение бюджетных прав автономии и др. В выступлениях представителей организаций русского населения, депутатов Верховного Совета Крыма протесты против языковой, образовательной, культурно-идеологической политики официального Киева обосновывались ссылками на международные правовые акты и законы Украины: Хартию региональных языков и языковых меньшинств, Конституцию Украины, Конституцию Автономной Республики Крым, законы Украины «Об образовании», «О языках», «О высшем образовании» и др. Ссылки на законы служили основанием для подачи исков в суды разных инстанций, вплоть до Конституционного суда.

Однако те, кто должен был реагировать на обращения и протесты русских организаций Крыма - международные организации гуманитарного профиля, - фактически не обращали внимания на эти акции, отказывались признавать наличие серьезных проблем у русского населения. По словам Сергея Цекова, протестные настроения (так называемый «сепаратизм») в среде русского населения они связывали главным образом с «подстрекательствами извне». Заявления же о том, что подобные настроения были вызваны прежде всего политикой официального Киева, порождали недовольство у западных наблюдателей, которые попросту переставали общаться с представителями пророссийских организаций. По сути, все то, что относилось к сфере прав русского 
населения - сохранение широкой сферы употребления русского языка, памяти об общем российском (советском) прошлом, - рассматривалось на Западе как «рудимент имперских притязаний России» и поэтому как бы изымалось из сферы деятельности правозащитных организаций. Лидеры русского движения в Крыму в своих выступлениях не раз подчеркивали, что подобный подход противоречит принципу верховенства прав человека как универсальной ценности.

Убедившись в недостаточной эффективности акций правозащитного характера, руководители организаций русского населения развернули широкую культурно-просветительскую деятельность, связанную с вопросами образования и исторического самосознания. Подобная деятельность получала зачастую довольно значительный размах и играла заметную роль в жизни полуострова. Так, Русской общиной Крыма и другими пророссийскими организациями были в 2008-2009 гг. организованы: массовые митинги протеста против празднования юбилеев исторических фигур, провозглашаемых официальным Киевом героями, - И. Мазепы и Р. Шухевича'. Устраивались также демонстрации против решения властей об украинизации кинопроката, акция «В каждом окне - российский флаг!», митинг в честь годовщины референдума 17 марта 1991 г. о сохранении СССР, автопробег в честь празднования Дня защитника Отечества (23 февраля) и др. К числу наиболее масштабных акций следует отнести организованный при активном участии Русской общины Крыма международный фестиваль «Великое русское слово», проходивший в ряде городов автономии с 6 по 12 июня 2009 г. (дата начала - день рождения А.С. Пушкина, дата завершения - День России). На фестивале присутствовали видные политики и официальные лица России, поздравление его участникам прислал президент России Д.А. Медведев. В рамках фестиваля был проведен ряд масштабных мероприятий: конференция «Русский язык в поликультурном мире», круглые столы «Украина и Россия - духовная и культурно-историческая общность», «СМИ Украины и России - шаги навстречу». По итогам фестиваля было принято решение о создании организации «Русскоязычная Украина», призванной заниматься правозащитной деятельностью. По мнению организаторов фестиваля - представителей русских организаций Крыма, само проведение такого мероприятия знаменовало выход пророссийского движения полуострова на новый уровень, говорило о наличии у него широких перспектив.

Интересы русского населения отстаивались также в ходе парламентской деятельности, тем более что после выборов 2006 г. Русская община Крыма и партия «Русский блок» заняли прочные позиции в Верховном Совете Крыма. По инициативе пророссийских организаций Верховный Совет принял в 2009 г. постановление «О мерах по поддержке русского языка в сфере образования в Автономной Республике Крым», а также постановление «О недопущении пропаганды фашизма и расовой нетерпимости, реабилитации и героизации фашистских коллаборационистов», направленное против внедряемых официальным Киевом новых историко-культурных символов (переоценка деятельности Украинской повстанческой армии, дивизии СС «Галичина» и др.). Вер-

1 Р. Шухевич - один из руководителей Украинской повстанческой армии, активно сотрудничал с нацистами, служил в подразделениях вермахта, имел звание гауптмана (капитана). 
ховный Совет протестовал против попытки киевских властей прекратить трансляцию на территории полуострова российских телепрограмм, против сокращения (в перспективе - прекращения) преподавания на русском языке в средних и высших учебных заведениях Крыма и др. Подобная деятельность, безусловно, способствовала привлечению внимания к проблемам русского населения Крыма и до известной степени сглаживала конфликты и противоречия в среде политических лидеров, выражавших интересы русской общины.

Подытожим сказанное.

Взгляды и настроения русского населения Крыма, выявившиеся в ходе событий 2014 г., прошли длительный процесс формирования и эволюции, на которую влиял целый ряд факторов. Исходной точкой были действия пророссийских организаций, выступивших при поддержке большинства населения в начале 1990-х годов за включение полуострова в состав России. Развернувшийся затем натиск официального Киева на автономию республики способствовал нарастанию протестных настроений в среде русского населения. Особо негативную реакцию вызывала политика в сфере образования и культуры, напрямую затрагивавшая вопросы языковой, национальной, исторической идентичности русской общины. Целый ряд организаций, общественных и политических деятелей Крыма выступил в защиту интересов русского населения. Однако при попытках объединить свои действия, придать им более целенаправленный характер они столкнулись с серьезными препятствиями, прежде всего - отсутствием твердо выраженной поддержки со стороны России, на которую эти организации и политики ориентировались. Споры в среде пророссийских деятелей вызывал и вопрос об отношении к украинскому государству: должен ли Крым пребывать в его составе (при условии обеспечения широкой автономии) или же необходимо бороться за независимость полуострова?

В конечном счете разногласия удалось преодолеть. В значительной степени этому способствовали предпринимавшиеся пророссийскими организациями Крыма культурнопросветительские начинания, призванные подчеркнуть исторические основы идентичности русского населения, закрепить в его сознании чувство связи с исторической родиной.

\section{Литература}

Виктор Янукович защищает только интересы олигархического клана: организация Севастополь-Крым-Россия // Regnum. 08.08.2006. — URL: regnum.ru/news/685803.html (дата обращения: 24.11.2019).

Грач Л. Партия регионов опять будет дурить украинский народ своей любовыю к России. Интервью // Regnum. 22.06.2007. — URL: regnum.ru/news/846818.html (дата обращения: 24.11.2019).

Декларация о провозглашении Народного фронта «Севастополь - Крым - Россия». 24 августа 2005 г. // Российское народное вече Севастополя. Веб-сайт Народного фронта «Севастополь — Крым - Россия». — URL: sevrus.narod.ru/\#v25 (дата обращения: 24.11.2019) 
Компаниец С. Мешков может вернуться в Крым» //Радио «Свобода», 16 июня 2006 г.

Крымчане отпраздновали день республики Крым. Из выступления секретаря Симферопольского городского Совета, члена Президиума Думы «Русской общины» В. Блинова на митинге в честь годовщины проведения референдума о воссоздании автономии в Крыму, 20 января 2009 г.

На Украине есть пороховая бочка, у которой много фитилей и нетрезвая охрана: Крым за неделю // Regnum. 04.03.2008. - URL: regnum.ru/news/966564.html (дата обращения: 24.11.2019)

Радивилов О. «Жареный петух» для русских крымчан. Интервью // Росбалт. 22.06.2009. URL: rosbalt.ru/2009/06/22/649201.html (дата обращения: 24.11.2019)

Скольких крымчан планируют убить США при добыче нефти на Черноморском шельфе? Крым за неделю // Regnum. 30.01.2009. — URL: regnum.ru/news/1117946.html (дата обращения: 24.11.2019).

Цеков С. Нет - политическим репрессиям в Крыму! Пресс-конференция Председателя Русской общины Крыма Сергея Цекова и руководителя правозащитной организации «Вера» Святослава Компанийца. 15 марта 2009 г. // Русская народная линия. 18.03.2009. — URL: ruskline.ru/analitika/2009/03/18/net_-_politicheskim_repressiyam_v_krymu(дата обращения: 24.11.2019). 